\title{
Respons pertumbuhan dan hasil tanaman hanjeli (Coix lacryma-jobi L.) terhadap kombinasi jarak tanam dan jenis pupuk kandang di dataran medium Sukasari, Sumedang
}

\section{Growth responses and yield of job's tears (Coix lacryma-jobi L.) to the combination plant spacing and manure type in medium plains Sukasari, Sumedang}

Diterima : 10 Juni 2019/Disetujui : 1 Agustus 2019 / Dipublikasikan : 7 Agustus 2019

CDepartment of Crop Science, Padjadjaran University

\begin{abstract}
The objectives of this experiment were to obtain the best of Plant Spacing and Manure Type for growth and yield of job's tears. This experiment was conducted from Desember 2015 to May 2016 at Sukasari Sumedang. Location of experiment have altitude of about \pm 800 metres above sea level and climate type was $C_{3}$ (Oldemann climate type). Experimental design used randomized block design (RBD), that consisted of nine treatments with three replications, so there are 27 experimental plots. The treatments were plant spacing $50 \times 50 \mathrm{~cm}+$ chicken manure 5 ton/ha, plant spacing $50 \times 50$ $\mathrm{cm}+$ goat manure 5 ton/ha, plant spacing $50 \mathrm{x}$ $50 \mathrm{~cm}+$ cow manure 5 ton/ha, plant spacing 50 x $75 \mathrm{~cm}+$ chicken manure 5 ton/ha, plant spacing $50 \times 75 \mathrm{~cm}+$ goat manure 5 ton/ha, plant spacing $50 \times 75 \mathrm{~cm}+$ cow manure 5 ton/ha, plant spacing $50 \times 100 \mathrm{~cm}+$ chicken manure 5 ton/ha, plant spacing $50 \times 100 \mathrm{~cm}+$ goat manure 5 ton/ha, plant spacing $50 \times 100 \mathrm{~cm}$ + cow manure 5 ton/ha. The result of this research showed that plant spacing and manure type affected leaf area index, root dry weight, and seed weight. Plant spacing $50 \times 75 \mathrm{~cm}+$ chicken manure 5 ton/ha gave a better effect on plant height, the number of leaves, number of tillers, and number of panicles.
\end{abstract}

Keywords: Job's tears $\cdot$ Plant spacing $\cdot$ Manure

\footnotetext{
Dikomunikasikan oleh Yuyun Yuwariah

Ruminta $^{1} \cdot$ Tati Nurmala ${ }^{2} \cdot$ Aep Wawan Irwan ${ }^{3} \cdot$ Yakup

Antonius Surbakti ${ }^{4}$

${ }^{1}$ Program Studi Agronomi Fakultas Pertanian UNPAD

${ }^{2}$ Program Studi Agronomi Fakultas Pertanian UNPAD

${ }^{3}$ Program Studi Agroteknologi Fakultas Pertanian UNPAD

n Program Studi Agroteknologi Fakultas Pertanian

UNPAD

Korespondensi: r_ruminta@yahoo.com.
}

Sari Penelitian ini bertujuan untuk mengetahui pengaruh jarak tanam dan jenis pupuk kandang yang memberikan pengaruh terbaik terhadap pertumbuhan dan hasil tanaman hanjeli (Coix Lacryma-jobi L.). Penelitian ini telah dilaksanakan dari bulan Desember 2015 hingga bulan Mei 2016 di desa Sindangsari, Sukasari, Sumedang. Lokasi penelitian memiliki ketinggian $\pm 800 \mathrm{~m}$ di atas permukaan laut $(\mathrm{dpl})$ termasuk tipe iklim $\mathrm{C}_{3}$ menurut klasifikasi Oldemann. Rancangan percobaan menggunakan Rancangan Acak Kelompok (RAK) terdiri dari sembilan perlakuan dengan tiga kali ulangan, sehingga total terdapat 27 petak percobaan, yaitu jarak tanam $50 \times 50 \mathrm{~cm}+$ pupuk kandang ayam 5 ton/ha, jarak tanam $50 \times 50 \mathrm{~cm}+$ pupuk kandang kambing 5 ton/ha, jarak tanam $50 \times 50$ $\mathrm{cm}+$ pupuk kandang sapi 5 ton/ha, jarak tanam $50 \times 75 \mathrm{~cm}+$ pupuk kandang ayam 5 ton/ha, jarak tanam $50 \times 75 \mathrm{~cm}+$ pupuk kandang kambing 5 ton/ha, jarak tanam $50 \times 75 \mathrm{~cm}+$ pupuk kandang sapi 5 ton/ha, jarak tanam $50 \mathrm{x}$ $100 \mathrm{~cm}+$ pupuk kandang ayam 5 ton/ha, jarak tanam $50 \times 100 \mathrm{~cm}+$ pupuk kandang kambing 5 ton/ha, jarak tanam $50 \times 100 \mathrm{~cm}+$ pupuk kandang sapi 5 ton/ha. Hasil penelitian menunjukkan adanya pengaruh jarak tanam dan jenis pupuk kandang terhadap indeks luas daun, bobot kering akar, dan bobot biji per rumpun. Secara keseluruhan perlakuan jarak tanam $50 x$ $75 \mathrm{~cm}+$ pupuk kandang ayam memberikan pengaruh lebih baik terhadap tinggi tanaman, jumlah daun, jumlah anakan, dan jumlah malai per rumpun.

Kata kunci: Hanjeli · Jarak tanam · Pupuk kandang 


\section{Pendahuluan}

Tanaman hanjeli (Coix lacryma-jobi L.) adalah sejenis tumbuhan serealia tropika dari suku padi-padian (Poaceae) yang berasal dari Asia Timur dan Malaya. Tanaman ini sekarang telah tersebar ke berbagai penjuru dunia (Marco dan Wunwisa, 2012). Dalam bahasa Inggris hanjeli disebut job's tears atau biasa juga disebut chinese pearl, sedangkan dalam bahasa daerah biasanya disebut jali betul, jali watu, jelali (Jawa), dan hanjeli (Sunda). Tanaman hanjeli dapat tumbuh di dataran rendah maupun dataran tinggi (Nurmala, 1998). Hanjeli tumbuh baik sampai ketinggian $1000 \mathrm{~m}$ di atas permukaan laut, sangat menyukai tanah yang lembab terbuka dengan suhu sekitar $25^{\circ} \mathrm{C}-35^{\circ} \mathrm{C}$ dan terkena sinar matahari langsung. Potensi produksi biji hanjeli dapat mencapai 4-6 ton/ha biji berkulit. Bulir hanjeli masak terbungkus struktur yang keras, berbentuk oval, dan berwarna putih.

Potensi tanaman hanjeli cukup besar. Hasil olahan biji hanjeli dapat dimanfaatkan sebagai alternatif pangan, yaitu sebagai bahan pembuat bubur, tape, dan bahan kue-kue yang menggunakan tepung hanjeli sebagai bahan campuran. Selain itu, tanaman hanjeli juga dapat dimanfaatkan sebagai makanan berkhasiat obat. Hanjeli memiliki kandungan karbohidrat yang tidak kalah dengan beras serta serealia lainnya. Sebagai salah satu tanaman pangan alternatif, tanaman hanjeli memiliki potensi yang cukup baik. Potensi yang dimiliki tanaman hanjeli ini harus ditunjang dengan teknik budidaya yang baik agar hasil yang didapatkan optimal. Salah satu contoh penerapan teknik budidaya yang harus diperhatikan diantaranya pengaturan jarak tanam dan penggunaan jenis pupuk kandang yang akan digunakan pada pertanaman tanaman hanjeli.

Jarak tanam merupakan salah satu faktor yang harus diperhatikan untuk mendapatkan pertumbuhan dan produksi yang optimal. Dengan pengaturan jarak tanam yang baik pada tanaman hanjeli dapat meningkatkan hasil melalui peningkatan populasi. Populasi yang terlalu padat karena jarak tanam yang terlalu dekat akan mengakibatkan tanaman berkompetisi dalam unsur hara, cahaya matahari, dan air, sehingga dibutuhkan jarak tanam yang tepat untuk pertumbuhan suatu tanaman. Menurut Harjadi (1993) jarak tanam akan mempengaruhi efisiensi penggunaan cahaya serta kompetisi antar tanaman dalam penggunaan air dan unsur hara yang akan mempengaruhi hasil. Silaban (1994) berpendapat bahwa adanya kecenderungan penurunan hasil disebabkan populasi yang tinggi, meningkatnya persaingan antara tanaman itu sendiri dalam memperoleh hara, air dan cahaya matahari.

Jarak tanam yang terlalu lebar kurang efisien dalam pemanfaatan lahan, sementara bila terlalu sempit akan terjadi persaingan yang tinggi yang mengakibatkan produktivitas rendah. Pengaturan jarak tanam pada tanaman budidaya dimaksudkan untuk menekan kompetisi antara tanaman. Setiap jenis tanaman mempunyai kepadatan populasi tanaman yang optimum untuk mendapatkan produksi yang maksimum. Pengaturan jarak tanam merupakan salah satu upaya agar tanaman dapat menyerap cahaya matahari dengan baik. Pengaturan jarak tanam membuat cahaya matahari dapat leluasa masuk ke sekitar tanaman. Cahyono (2002) menjelaskan bahwa pengaturan jarak tanam yang sesuai dengan jenis tanaman akan berpengaruh baik terhadap pertumbuhan dan perkembangan tanaman. Menurut Purwanto dan Rudi (2005), semakin panjang umur tanaman maka tanaman akan semakin tinggi dan memerlukan tempat yang lebih luas. Jarak tanam pada tanaman hanjeli bergantung pada jenis varietasnya, namun pada umumnya jarak tanam yang digunakan untuk tanaman hanjeli adalah $40 \times 60$ $\mathrm{cm}, 60 \times 30 \mathrm{~cm}$, dan $60 \times 60 \mathrm{~cm}$ (Nurmala dan Irwan, 2007). Jarak tanam yang lebih lebar memudahkan untuk penyebaran sistem perakaran. Jarak tanam yang lebih lebar akan berpengaruh terhadap efisiensi penggunaan tempat dan pemberian pupuk.

Selain pengaturan jarak tanam, upaya yang dapat dilakukan untuk meningkatkan pertumbuhan dan perkembangan serta kualitas hasil tanaman hanjeli adalah dengan memberikan suplai hara yang cukup dan seimbang melalui pemupukan yang dapat memperbaiki kondisi tanah dengan cara penambahan pupuk organik dalam tanah. Pupuk organik adalah pupuk yang sebagian besar atau seluruhnya terdiri atas bahan organik yang berasal dari tanaman dan atau hewan yang telah melalui proses rekayasa. Pupuk organik dapat berbentuk padat atau cair yang digunakan mensuplai bahan organik untuk memperbaiki sifat fisik, kimia, dan biologi 
tanah (Suriadikarta dan Simanungkalit, 2006). Salah satu pupuk organik yang dapat diberikan adalah pupuk kandang yang berasal dari kandang ternak berupa kotorannya. Pupuk kandang dapat menambah kandungan bahan organik atau humus yang memperbaiki sifat fisika tanah terutama struktur tanah, daya mengikat air, dan porositas tanah. Pupuk kandang juga dapat memperbaiki sifat biologi tanah yaitu dalam memperbaiki kehidupan mikroorganisme tanah dan melindungi tanah dari kerusakan yang disebabkan oleh erosi. Jenis pupuk kandang umumnya adalah pupuk kandang ayam, pupuk kandang kambing, dan pupuk kandang sapi. Pemilihan jenis pupuk kandang yang sesuai dengan kebutuhan tanaman akan menunjang pertumbuhan dan hasil tanaman itu sendiri.

Pupuk kandang tersebut mengandung unsur hara yang berbeda-beda sesuai dengan jenis hewan, umur hewan, makanan hewan, hamparan yang digunakan, dan cara penyimpanan (Sutedjo, 2008). Pemilihan jenis pupuk kandang perlu dipertimbangkan, selain karena mempertimbangkan kandungan pupuk yang diperlukan untuk tanaman, diperlukan juga pertimbangan yang baik agar tidak berkembangnya gulma dengan cepat pada lahan yang diusahakan. Diketahui bahwa keberadaan gulma yang dibiarkan tumbuh pada suatu pertanaman dapat menurunkan hasil 20\% sampai 80\% (Moenandir et. al., 1993). Salah satu usaha yang dapat dilakukan untuk menekan hal tersebut adalah dengan penggunaan jenis pupuk kandang yang tepat.

Hasil peneltian Maruapey (2011) menunjukkan bahwa pemberian pupuk kandang ayam yang dikombinasikan dengan jarak tanam $60 \mathrm{~cm} \times 60 \mathrm{~cm}$ pada tanaman jagung menghasilkan tongkol layak jual tertinggi yaitu 11,576 ton/ha, meningkat sebesar $47,03 \%$ bila dibandingkan dengan hasil terendah yang diperoleh pada perlakukan tanpa pupuk kandang yang dikombinasikan dengan jarak tanam $100 \mathrm{~cm} \times$ $40 \mathrm{~cm}$, yaitu sebesar 6,127 ton/ha.

Berdasarkan uraian tersebut, maka perlu dilakukan penelitian mengenai pengaruh pengaturan jarak tanam ditambah dengan pemberian jenis pupuk kandang terhadap pertumbuhan dan hasil tanaman hanjeli. Pengaturan jarak tanam dan pemberian pupuk kandang diharapkan akan mampu meningkatkan pertumbuhan dan hasil tanaman hanjeli. Kegunaan penelitian ini adalah dapat digunakan sebagai informasi dalam pengaturan jarak tanam dan pemilihan jenis pupuk kandang untuk menghasilkan tanaman hanjeli dengan pertumbuhan dan hasil tanaman hanjeli yang optimal.

\section{Bahan dan Metode}

Percobaan dilaksanakan di Desa Sindangsari, Kecamatan Sukasari, Kabupaten Sumedang. Tempat penelitian terletak pada ketinggian \pm 800 $m$ di atas permukaan laut. Tipe iklimnya termasuk tipe $\mathrm{C}_{3}$ (agak basah) menurut klasifikasi Oldemann (1975). Percobaan dilakukan dari bulan Desember 2015 sampai dengan bulan Mei 2016. Bahan-bahan yang digunakan dalam percobaan adalah benih Hanjeli Pulut aksesi 37 (benih dari koleksi Laboratorium Produksi dan Pemuliaan Tanaman, Fakultas Pertanian, Universitas Padjadjaran), pestisida karbofuran, pupuk kandang ayam, pupuk kandang domba, pupuk kandang sapi, pupuk NPK majemuk (15:15:15), dan pestisida. Alat yang digunakan adalah alat pengolah tanah, alat menanam, alat pemeliharaan tanaman, alat panen, alat pasca panen, serta alat pengamatan dan analisis data pengamatan. Rancangan percobaan yang digunakan adalah Rancangan Acak Kelompok (RAK). Perlakuan terdiri dari 9 perlakuan dan diulang sebanyak $3 \mathrm{kali}$, dengan demikian terdapat 27 satuan perlakuan. Setiap petak percobaan berukuran $4 \mathrm{~m} \times 2 \mathrm{~m}$. Perlakuan yang diberikan sebagai berikut:

A. Jarak tanam $50 \times 50 \mathrm{~cm}$ dengan pupuk kandang ayam 5 ton/ha

B. Jarak tanam $50 \times 50 \mathrm{~cm}$ dengan pupuk kandang kambing 5 ton/ha

C. Jarak tanam $50 \times 50 \mathrm{~cm}$ dengan pupuk kandang sapi 5 ton/ha

D. Jarak tanam $50 \times 75 \mathrm{~cm}$ dengan pupuk kandang ayam 5 ton/ha

E. Jarak tanam $50 \times 75 \mathrm{~cm}$ dengan pupuk kandang kambing 5 ton/ha

F. Jarak tanam $50 \times 75 \mathrm{~cm}$ dengan pupuk kandang sapi 5 ton/ha

G. Jarak tanam $50 \times 100 \mathrm{~cm}$ dengan pupuk kandang ayam 5 ton/ha

H. Jarak tanam $50 \times 100 \mathrm{~cm}$ dengan pupuk kandang kambing 5 ton/ha

I. Jarak tanam $50 \times 100 \mathrm{~cm}$ dengan pupuk kandang sapi 5 ton/ha

Pelaksanaan teknik budidaya, seperti pengolahan lahan, penanaman, pemeliharaan, 
panen, pemupukan NPK, pengendalian hama dan penyakit tanaman, serta pengendalian gulma dilakukan secara sama/ homogen. Dalam penelitian ini data yang diamati adalah variabel pertumbuhan tanaman seperti tinggi tanaman, jumlah daun, jumlah anakan per rumpun, indeks luas daun (ILD), biomassa tanaman total, dan jumlah srisip per rumpun. Pengamatan juga dilakukan terhadap variabel hasil, yaitu jumlah malai per rumpun, jumlah biji per rumpun, nisbah pupus akar (NPA), bobot biji per rumpun, bobot 100 butir, rendemen biji pecah kulit, dan indeks panen. Uji statistik yang digunakan untuk mengetahui pengaruh perlakuan yang diaplikasikan adalah uji $\mathrm{F}$, yang dilakukan dengan menguji peluang dari variasi diantara nilai rata-rata perlakuan untuk mengetahui minimal sepasang perlakuan yang berbeda nyata. Jika nilai $\mathrm{F}$ hitung $>\mathrm{F}$ tabel pada taraf nyata $5 \%$, maka dapat dinyatakan bahwa terdapat minimal sepasang perlakuan yang berbeda nyata. Jika dari analisis ragam nilai $\mathrm{F}$ hitung $>\mathrm{F}$ tabel, maka dilanjutkan dengan uji Duncan pada taraf nyata 5\% untuk menguji perbedaan antar masing-masing nilai rata-rata perlakuan. Analisis data hasil pengamatan menggunakan Software SPSS versi 17.

\section{Hasil dan Pembahasan}

Tinggi Tanaman. Hasil analisis ragam mengenai tinggi tanaman hanjeli disajikan pada Tabel 1 . Tinggi tanaman merupakan ukuran tanaman yang diamati sebagai indikator pertumbuhan atau sebagai parameter yang digunakan untuk mengukur pengaruh lingkungan ataupun perlakuan yang diterapkan (Sitompul dan Guritno, 1995). Berdasarkan Tabel 1 diketahui bahwa pengaturan jarak tanam dan jenis pupuk kandang menunjukkan pengaruh yang tidak berbeda nyata pada setiap perlakuan terhadap tinggi tanaman. Namun demikian, perlakuan jarak tanam $50 \times 75 \mathrm{~cm}$ dengan pupuk kandang ayam 5 ton/ha memiliki potensi tinggi tanaman yang tinggi, yakni mencapai $154,08 \mathrm{~cm}$ dan perlakuan jarak tanam $50 \times 100 \mathrm{~cm}$ dengan pupuk kandang sapi 5 ton/ha memiliki potensi tinggi tanaman yang rendah yakni mencapai 137,83 bila dibandingkan dengan perlakuan lainnya. Hasil yang tidak berpengaruh nyata diduga karena kondisi lingkungan yang mendukung, seperti curah hujan, suhu, dan kelembaban. Selain itu, ketersediaan unsur yang dibutuhkan di dalam tanah sudah mencukupi dan kandungan hara pada jenis pupuk kandang yang digunakan sebagai perlakuan tidak terlalu berbeda nyata.

Tabel 1 menunjukkan bahwa hampir seluruh perlakuan jarak tanam dan jenis pupuk kandang memberikan pertumbuhan yang baik dan melampaui penelitian sebelumnya. Pertumbuhan tinggi tanaman yang baik dapat mempengaruhi intensitas cahaya matahari yang diterima oleh tanaman hanjeli. Semakin mudah tanaman mendapatkan akses cahaya matahari, maka akan semakin berpengaruh terhadap banyaknya energi yang digunakan dalam proses fotosintesis. Menurut Kuyik et. al. (2012), fotosintesis adalah proses dasar pada tanaman untuk menghasilkan makanan. Makanan yang dihasilkan akan menentukan ketersediaan energi untuk pertumbuhan dan perkembangan tanaman. Cahaya merupakan faktor penting terhadap berlangsungnya fotosintesis, sementara fotosintesis merupakan proses yang menjadi kunci dapat berlangsungnya proses metabolisme yang lain di dalam tanaman. Pertumbuhan tinggi yang baik pada percobaan ini juga didukung dengan keadaan lingkungan selama percobaan yang optimal. Selain peran kondisi lingkungan, pemberian pupuk kandang dianggap cukup memenuhi kebutuhan tanaman.

Jumlah Daun. Daun merupakan organ untuk proses fotosintesis tanaman. Jumlah daun dapat dijadikan salah satu parameter untuk pertumbuhan vegetatif. Hasil analisis ragam mengenai jumlah daun disajikan pada Tabel 1 . Berdasarkan Tabel 1 diketahui bahwa pengaturan jarak tanam dan jenis pupuk kandang menunjukkan pengaruh yang tidak berbeda nyata pada setiap perlakuan terhadap jumlah daun. Perlakuan jarak tanam $50 \times 75 \mathrm{~cm}$ dengan pupuk kandang ayam 5 ton/ha memiliki jumlah daun yang banyak yakni mencapai 60,33 dan perlakuan jarak tanam $50 \mathrm{x}$ $100 \mathrm{~cm}$ dengan pupuk kandang sapi 5 ton/ha memiliki jumlah daun kecil yakni mencapai 49,33 bila dibandingkan dengan perlakuan lainnya. Hasil yang tidak berpengaruh nyata diduga karena ketersediaan unsur hara di dalam tanah mencukupi untuk pertumbuhan tanaman hanjeli seperti unsur N. Nitrogen membantu pembentukan atau pertumbuhan bagian vegetatif tanaman, seperti daun, batang dan akar. Selain itu, N berperan penting dalam hal pembentukan hijau daun yang berguna sekali 
dalam proses fotosintesis. Kondisi lingkungan yang optimal juga berperan dalam pertumbuhan tanaman hanjeli.

Jumlah Anakan per Rumpun. Hasil analisis ragam mengenai jumlah anakan per rumpun disajikan pada Tabel 1. Berdasarkan Tabel 1 diketahui bahwa pengaturan jarak tanam dan jenis pupuk kandang menunjukkan pengaruh yang tidak berbeda nyata pada setiap perlakuan terhadap jumlah anakan per rumpun. Hal tersebut sejalan dengan pendapat Yelis (2011) yang menyatakan bahwa jumlah anakan lebih ditentukan oleh varietas yang digunakan. Anakan mulai terbentuk pada saat tanaman berumur 10 HST dan mencapai jumlah maksimalnya pada umur 50-60 HST.

Jumlah Srisip per Rumpun. Hasil analisis ragam mengenai jumlah srisip per rumpun disajikan pada Tabel 1. Berdasarkan hasil analisis data statistik pada Tabel 1 diketahui bahwa pengaturan jarak tanam dan jenis pupuk kandang menunjukkan pengaruh tidak berbeda nyata pada setiap perlakuan terhadap jumlah srisip per rumpun tanaman hanjeli. Hal tersebut sejalan dengan pendapat Yelis (2011), yang menyatakan bahwa jumlah srisip lebih ditentukan oleh varietas yang digunakan, sama halnya dengan jumlah anakan.

Indeks Luas Daun. Indeks luas daun (ILD) dapat menggambarkan ukuran kasar luas daun per satuan radiasi matahari yang tersedia. Indeks luas daun merupakan rasio antara luas daun dengan luas areal tanaman. Analisis ragam mengenai indeks luas daun disajikan pada Tabel 2. Berdasarkan hasil analisis data statistik pada Tabel 2 diketahui bahwa pengaturan jarak tanam dan jenis pupuk kandang menunjukkan pengaruh nyata. Menurut Gardner dan Pearce (1991) kisaran nilai indeks daun yang optimal bagi tanaman budidaya antara lain 3 sampai 5 . Pada percobaan ini, indeks luas daun tertinggi terdapat pada perlakuan $\mathrm{C}$ dengan nilai indeks luas daunnya 4,34 dan perlakuan $\mathrm{H}$ memiliki nilai indeks luas daun terkecil yaitu 2,10.

Menurut Goldsworthy dan Fischer (1992), faktor yang dapat mempengaruhi besarnya indeks luas daun antara lain adalah jarak tanam dan penyediaan unsur hara nitrogen. Jarak tanam secara langsung dapat mempengaruhi kerapatan populasi suatu tanaman. Nitrogen adalah salah satu unsur hara makro essensial bagi tanaman yang diperlukan dalam pembentukan dan pertumbuhan vegetatif tanaman dan sebagai bahan dasar penyusunan protein serta pembentukkan klorofil. Di samping itu menurut Gardner dan Pearce (1991), ILD merupakan parameter yang menunjukkan potensi tanaman melakukan fotosintesis dan juga potensi produktif tanaman di lapangan. ILD yang tinggi dapat menurunkan hasil karena daun yang paling bawah terus melakukan respirasi yang lebih besar daripada yang dihasilkan pada proses fotosintesis sehingga pembagian fotosintat ke organ lain berkurang. ILD yang tinggi akan menguntungkan jika hasil yang diiinginkan adalah biomassa, tetapi bagi tanaman yang dihasilkannya biji, hal tersebut tidak menguntungkan karena tidak tersedianya fotosintat berlebih untuk menghasilkan biji.

Biomassa Tanaman. Biomassa memiliki pengertian massa bagian hidup tanaman. Biomassa tanaman adalah parameter yang digunakan untuk menggambarkan dan mempelajari pertumbuhan tanaman. Biomassa tanaman

Tabel 1. Pengaruh jarak tanam dan jenis pupuk kandang terhadap tinggi tanaman hanjeli, jumlah daun, jumlah anakan, dan jumlah srisip.

\begin{tabular}{|c|c|c|c|c|}
\hline Perlakuan & $\begin{array}{c}\text { Tinggi Tanaman } \\
(\mathrm{cm})\end{array}$ & $\begin{array}{l}\text { Jumlah } \\
\text { Daun }\end{array}$ & $\begin{array}{l}\text { Jumlah } \\
\text { Anakan }\end{array}$ & $\begin{array}{l}\text { Jumlah } \\
\text { Srisip }\end{array}$ \\
\hline $\mathrm{A}=\mathrm{JK} 50 \times 50 \mathrm{~cm}+\mathrm{PK}$ ayam 5 ton $/ \mathrm{ha}$ & $152,42 \mathrm{a}$ & $50,33 \mathrm{a}$ & $10,33 \mathrm{a}$ & $99.22 \mathrm{a}$ \\
\hline $\mathrm{B}=\mathrm{JK} 50 \times 50 \mathrm{~cm}+\mathrm{PK}$ kambing 5 ton $/$ ha & $143,67 \mathrm{a}$ & $50,00 \mathrm{a}$ & $10,33 \mathrm{a}$ & $95.78 \mathrm{a}$ \\
\hline $\mathrm{C}=\mathrm{JK} 50 \times 50 \mathrm{~cm}+\mathrm{PK}$ sapi $5 \mathrm{ton} / \mathrm{ha}$ & $142,75 \mathrm{a}$ & $60,00 \mathrm{a}$ & $12,67 \mathrm{a}$ & $94.33 \mathrm{a}$ \\
\hline $\mathrm{D}=\mathrm{JK} 50 \times 75 \mathrm{~cm}+\mathrm{PK}$ ayam 5 ton $/$ ha & $154,08 \mathrm{a}$ & $60,33 \mathrm{a}$ & $10,67 \mathrm{a}$ & $104.56 \mathrm{a}$ \\
\hline $\mathrm{E}=\mathrm{JK} 50 \times 75 \mathrm{~cm}+\mathrm{PK}$ kambing 5 ton $/$ ha & 138,83 a & $58,67 \mathrm{a}$ & 10,67 a & $98.33 \mathrm{a}$ \\
\hline $\mathrm{F}=\mathrm{JK} 50 \times 75 \mathrm{~cm}+\mathrm{PK}$ sapi 5 ton $/ \mathrm{ha}$ & 137,92 a & $56,33 \mathrm{a}$ & $10,00 \mathrm{a}$ & $100.44 \mathrm{a}$ \\
\hline $\mathrm{G}=\mathrm{JK} 50 \times 100 \mathrm{~cm}+\mathrm{PK}$ ayam 5 ton $/ \mathrm{ha}$ & 143,08 a & 57,67 a & 12,33 a & $104.67 \mathrm{a}$ \\
\hline $\mathrm{H}=\mathrm{JK} 50 \times 100 \mathrm{~cm}+\mathrm{PK}$ kambing 5 ton $/$ ha & 142,83 a & $51,00 \mathrm{a}$ & 11,67 a & $97.78 \mathrm{a}$ \\
\hline $\mathrm{I}=\mathrm{JK} 50 \times 100 \mathrm{~cm}+\mathrm{PK}$ sapi 5 ton $/ \mathrm{ha}$ & $137,83 \mathrm{a}$ & 49,33 a & $9,00 \mathrm{a}$ & $95.88 \mathrm{a}$ \\
\hline
\end{tabular}

Keterangan : JK = Jarak Tanam dan PK = Pupuk Kandang

Huruf yang sama setelah nilai rata-rata menunjukkan perbedaan yang nyata menurut uji Duncan pada taraf nyata $5 \%$ 
Tabel 2. Pengaruh Jarak Tanam dan Jenis Pupuk Kandang Terhadap Indeks Luas Daun (ILD), Biomassa, Jumlah Malai per Rumpun, dan Jumlah Biji per Rumpun.

\begin{tabular}{|c|c|c|c|c|}
\hline Perlakuan & ILD & $\begin{array}{l}\text { Biomassa } \\
\text { (g) }\end{array}$ & $\begin{array}{l}\text { Jumlah Malai } \\
\text { per Rumpun }\end{array}$ & $\begin{array}{l}\text { Jumlah Biji per } \\
\text { Rumpun }\end{array}$ \\
\hline $\mathrm{A}=\mathrm{JK} 50 \times 50 \mathrm{~cm}+\mathrm{PK}$ ayam 5 ton $/ \mathrm{ha}$ & $3.77 \mathrm{ab}$ & $762.80 \mathrm{a}$ & $396.89 \mathrm{a}$ & $1582.47 \mathrm{a}$ \\
\hline $\mathrm{B}=\mathrm{JK} 50 \times 50 \mathrm{~cm}+\mathrm{PK}$ kambing 5 ton $/$ ha & $3.77 \mathrm{ab}$ & $751.27 \mathrm{a}$ & $383.09 \mathrm{a}$ & $1601.80 \mathrm{a}$ \\
\hline $\mathrm{C}=\mathrm{JK} 50 \times 50 \mathrm{~cm}+\mathrm{PK}$ sapi 5 ton $/ \mathrm{ha}$ & $4.34 \mathrm{a}$ & $877.37 \mathrm{a}$ & 377.33 a & $1568.23 \mathrm{a}$ \\
\hline $\mathrm{D}=\mathrm{JK} 50 \times 75 \mathrm{~cm}+\mathrm{PK}$ ayam 5 ton $/ \mathrm{ha}$ & $2.93 \mathrm{bc}$ & 755.33 a & $418.27 \mathrm{a}$ & $1663.39 \mathrm{a}$ \\
\hline $\mathrm{E}=\mathrm{JK} 50 \times 75 \mathrm{~cm}+\mathrm{PK}$ kambing 5 ton $/$ ha & $3.55 \mathrm{ab}$ & 815.80 a & 393.33 a & $1598.16 \mathrm{a}$ \\
\hline $\mathrm{F}=\mathrm{JK} 50 \times 75 \mathrm{~cm}+\mathrm{PK}$ sapi 5 ton $/ \mathrm{ha}$ & $3.05 \mathrm{bc}$ & $773.90 \mathrm{a}$ & $401.77 \mathrm{a}$ & $1615.38 \mathrm{a}$ \\
\hline $\mathrm{G}=\mathrm{JK} 50 \times 100 \mathrm{~cm}+\mathrm{PK}$ ayam 5 ton $/ \mathrm{ha}$ & $2.21 \mathrm{c}$ & 781.93 a & 418.68 a & $1719.64 \mathrm{a}$ \\
\hline $\mathrm{H}=\mathrm{JK} 50 \times 100 \mathrm{~cm}+\mathrm{PK}$ kambing 5 ton $/$ ha & $2.10 \mathrm{c}$ & $850.20 \mathrm{a}$ & $391.12 \mathrm{a}$ & $1695.72 \mathrm{a}$ \\
\hline $\mathrm{I}=\mathrm{JK} 50 \times 100 \mathrm{~cm}+\mathrm{PK}$ sapi 5 ton $/$ ha & $2.19 \mathrm{C}$ & $756.20 \mathrm{a}$ & $383.55 \mathrm{a}$ & $1775.00 \mathrm{a}$ \\
\hline
\end{tabular}

Keterangan : JK $=$ Jarak Tanam dan PK $=$ Pupuk Kandang

Huruf yang sama setelah nilai rata-rata menunjukkan perbedaan yang nyata menurut uji Duncan pada taraf nyata $5 \%$

merupakan integrasi dari hampir semua peristiwa yang dialami tanaman sebelumnya. Pengukuran biomassa tanaman dilakukan dengan cara menimbang bahan tanaman yang sudah dikeringkan. Hal tersebut bertujuan untuk menghilangkan semua kandungan air bahan, yang dilaksanakan pada suhu yang relatif tinggi selama jangka waktu tertentu (Sitompul dan Guritno, 1995). Analisis ragam mengenai biomassa tanaman disajikan pada Tabel 2. Berdasarkan hasil analisis data statistik pada Tabel 2 diketahui bahwa pengaturan jarak tanam dan jenis pupuk kandang menunjukkan pengaruh tidak berbeda nyata pada setiap perlakuan. Biomassa yang tinggi yaitu pada perlakuan C dengan bobot 877,37 gram dan biomassa yang kecil terdapat pada perlakuan D dengan bobot 755,33 gram.

Salisbury dan Ross (1995) menyatakan bahwa penyerapan garam mineral sebagian dikendalikan oleh aktivitas pupus. Pupus akan meningkatkan penyerapan garam mineral oleh akar dengan cepat dalam garam mineral tersebut pada produk pertumbuhan (misalnya protein, asam nukleat, dan klorofil). Pupus juga memasok akar dengan beberapa hormon tertentu yang dapat meningkatkan penyerapan unsur hara oleh akar. Dengan demikian, produk pertumbuhan berupa akumulasi fotosintat pada pupus akan meningkat yang menyebabkan serapan unsur hara meningkat pula, begitu juga sebaliknya. Bobot biomassa mencerminkan tingkat pertumbuhan tanaman yang ditentukan oleh kecukupan hara terutama nitrogen.

Jumlah Malai per Rumpun. Analisis ragam mengenai jumlah malai per rumpun disajikan pada Tabel 2. Berdasarkan hasil analisis data statistik pada Tabel 2 menunjukkan bahwa pengaturan jarak tanam dan jenis pupuk kandang menunjukkan pengaruh tidak berbeda nyata pada setiap perlakuan terhadap jumlah malai per rumpun tanaman hanjeli. Hal tersebut diduga karena jumlah malai tidak dipengaruhi oleh pengurangan atau penambahan unsur hara tetapi ditentukan oleh faktor genetik tanaman itu sendiri. Produksi malai dipengaruhi oleh banyak hal, terutama penyerapan unsur hara yang dibutuhkan untuk membentuk malai. Unsur nitrogen banyak diperlukan pada awal fase vegetatif untuk memperbanyak jumlah malai per tanaman dan pada fase reproduktif untuk pengisian bulir. Kekurangan unsur nitrogen menyebabkan malai mudah mati. Fosfor dan kalium juga diperlukan dalam pembentukan malai. Kekurangan fosfor dapat menyebabkan pembentukan malai yang tidak normal, begitu pula dengan kekurangan kalium.

Jumlah Biji per Rumpun. Hasil analisis ragam mengenai jumlah biji per rumpun disajikan pada Tabel 2. Hasil biji lebih banyak ditentukan oleh kondisi optimum dari fase pertumbuhan tanaman seperti periode pembungaan, pengisian biji, pematangan, dan pemasakan. Proses tersebut berhubungan dengan total luas daun pada fase pembungaan yang dapat berpengaruh terhadap ketersediaan fotosintat pada malai (Siarudin dan Suhaendah, 2007). Berdasarkan hasil analisis data statistik pada Tabel 2 diketahui bahwa pengaturan jarak tanam dan jenis pupuk kandang menunjukkan pengaruh tidak berbeda nyata pada setiap perlakuan terhadap jumlah biji per rumpun. Hal ini diduga karena faktor genetik dan ketersediaan unsur hara pembentuk biji yang relatif sama banyaknya. 
Jumlah biji per rumpun ditentukan dari bobot 100 butir dan bobot biji per rumpun. Jika bobot 100 biji lebih besar dari yang seharusnya pada suatu bobot biji per rumpun, maka jumlah biji yang didapatkan akan lebih sedikit dan begitu pun sebaliknya. Semakin besar bobot biji per rumpun dan semakin kecil bobot 100 biji maka semakin banyak jumlah biji per rumpunnya, demikian pun sebaliknya.

Bobot Kering Pupus. Produksi bahan kering tanaman tergantung dari penyinaran matahari dan pengambilan karbon dioksida serta air dalam tumbuhan. Hasil tanaman mensyaratkan penggunaan sumber daya iklim yang mencakup penyinaran matahari, pengambilan karbon dioksida, dan penggunaan air secara efisien (Sudaryani dan Sugiharti, 1989). Hasil analisis ragam mengenai bobot kering pupus disajikan pada Tabel 3. Berdasarkan hasil analisis data statistik pada Tabel 3 diketahui bahwa pengaturan jarak tanam dan jenis pupuk kandang menunjukkan pengaruh tidak berbeda nyata pada setiap perlakuan terhadap berat kering pupus tanaman hanjeli. Pada tanaman yang mengalami cekaman kekeringan, proses fotosintesis terganggu dan laju fotosintesis lebih lambat. Asimilat yang dihasilkan akan berlebih sehingga distribusi asimilat ke organ-organ tanaman menjadi lebih rendah, sehingga bobot kering tanaman berkurang (Rajagopal dan Beringer, 1982).

Bobot Kering Akar. Hasil analisis ragam mengenai bobot kering akar disajikan pada Tabel 3. Berdasarkan hasil analisis data statistik pada Tabel 3 diketahui bahwa pengaturan jarak tanam dan jenis pupuk kandang menunjukkan pengaruh nyata. Perlakuan $\mathrm{H}$ tidak berbeda nyata dengan perlakuan D, E, F, G dan I, namun berbeda nyata terhadap perlakuan A, B, dan C. Hal ini diduga karena pengaruh jarak tanam yang rapat akan membuat persaingan memperebutkan unsur hara di dalam tanah oleh akar.

Nisbah Pupus Akar (NPA). Hasil analisis ragam mengenai Nisbah Pupus Akar disajikan pada Tabel 3. Berdasarkan hasil analisis data statistik pada Tabel 3 diketahui bahwa pengaturan jarak tanam dan jenis pupuk kandang menunjukkan pengaruh tidak berbeda nyata pada setiap perlakuan terhadap nisbah pupus akar tanaman hanjeli. Nisbah pupus akar yang benilai lebih dari satu menunjukkan pertumbuhan tanaman lebih ke arah pupus, sedangkan nisbah pupus akar yang bernilai kurang dari satu menunjukkan pertumbuhan tanaman lebih kearah akar. Menurut Nurmala dan Irwan (2007), Nisbah Pupus akar yang ideal bagi tanaman pangan bernilai 3. Nisbah Pupus Akar yang bernilai lebih dari 3 diduga karena perlakuan pemberian pupuk dan juga faktor tanaman itu sendiri (genetik). Pemberian pupuk menyebabkan pertumbuhan lebih baik sehingga bobot pupus lebih besar, diikuti dengan bobot akar hanya saja bobot pupus akan lebih besar pertambahannya dibandingkan akar karena faktor genetik dari tanaman hanjeli tersebut.

Bobot 100 Butir. Hasil analisis ragam mengenai bobot 100 butir disajikan pada Tabel 3. Berdasarkan hasil analisis data statistik pada Tabel 3 diketahui bahwa pengaturan jarak tanam dan jenis pupuk kandang menunjukkan pengaruh tidak berbeda nyata pada setiap perlakuan terhadap bobot 100 butir tanaman hanjeli. Hal ini diduga karena faktor genetik dan juga penanaman pada kondisi lingkungan yang seragam.

Tabel 3. Pengaruh Jarak Tanam dan Jenis Pupuk Kandang Terhadap Bobot Kering Pupus, Bobot Kering Akar, Nisbah Pupus Akar, dan Bobot 100 Biji.

\begin{tabular}{|c|c|c|c|c|}
\hline Perlakuan & $\begin{array}{c}\text { Bobot Kering } \\
\text { Pupus (g) }\end{array}$ & $\begin{array}{c}\text { Bobot Kering } \\
\text { Akar }(\mathrm{g})\end{array}$ & $\begin{array}{c}\text { Nisbah } \\
\text { Pupus Akar }\end{array}$ & $\begin{array}{c}\text { Bobot } 100 \\
\text { Butir (g) }\end{array}$ \\
\hline $\mathrm{A}=\mathrm{JK} 50 \times 50 \mathrm{~cm}+\mathrm{PK}$ ayam $5 \mathrm{ton} / \mathrm{ha}$ & $418.80 \mathrm{a}$ & $77.80 \mathrm{bc}$ & $5.38 \mathrm{a}$ & $12.33 \mathrm{a}$ \\
\hline $\mathrm{B}=\mathrm{JK} 50 \times 50 \mathrm{~cm}+\mathrm{PK}$ kambing 5 ton $/$ ha & $407.27 \mathrm{a}$ & 71.73 c & $5.74 \mathrm{a}$ & $12.67 \mathrm{a}$ \\
\hline $\mathrm{C}=\mathrm{JK} 50 \times 50 \mathrm{~cm}+\mathrm{PK}$ sapi 5 ton $/$ ha & $533.37 \mathrm{a}$ & $78.70 \mathrm{bc}$ & $6.78 \mathrm{a}$ & $12.33 \mathrm{a}$ \\
\hline $\mathrm{D}=\mathrm{JK} 50 \times 75 \mathrm{~cm}+\mathrm{PK}$ ayam 5 ton $/ \mathrm{ha}$ & $411.33 \mathrm{a}$ & $83.77 \mathrm{abc}$ & $5.11 \mathrm{a}$ & $12.67 \mathrm{a}$ \\
\hline $\mathrm{E}=\mathrm{JK} 50 \times 75 \mathrm{~cm}+\mathrm{PK}$ kambing 5 ton $/$ ha & $471.80 \mathrm{a}$ & $87.37 \mathrm{ab}$ & $5.41 \mathrm{a}$ & $12.67 \mathrm{a}$ \\
\hline $\mathrm{F}=\mathrm{JK} 50 \times 75 \mathrm{~cm}+\mathrm{PK}$ sapi 5 ton $/$ ha & $429.90 \mathrm{a}$ & $82.73 \mathrm{abc}$ & $5.17 \mathrm{a}$ & $13.00 \mathrm{a}$ \\
\hline $\begin{array}{l}\mathrm{G}=\mathrm{JK} 50 \times 100 \mathrm{~cm}+\mathrm{PK} \text { ayam } 5 \text { ton } / \text { ha } \\
\mathrm{H}=\mathrm{JK} 50 \times 100 \mathrm{~cm}+\mathrm{PK} \text { kambing } 5\end{array}$ & $437.93 \mathrm{a}$ & $93.13 \mathrm{a}$ & $4.72 \mathrm{a}$ & $13.00 \mathrm{a}$ \\
\hline ton/ha & $506.20 \mathrm{a}$ & $94.33 \mathrm{a}$ & $5.36 \mathrm{a}$ & $13.00 \mathrm{a}$ \\
\hline $\mathrm{I}=\mathrm{JK} 50 \times 100 \mathrm{~cm}+\mathrm{PK}$ sapi 5 ton $/ \mathrm{ha}$ & $412.20 \mathrm{a}$ & $86.80 \mathrm{ab}$ & $4.82 \mathrm{a}$ & $12.00 \mathrm{a}$ \\
\hline
\end{tabular}

Keterangan : JK = Jarak Tanam dan PK = Pupuk Kandang

Huruf yang sama setelah nilai rata-rata menunjukkan perbedaan yang nyata menurut uji Duncan pada taraf nyata 5\% 
Tabel 4. Pengaruh Jarak Tanam dan Jenis Pupuk Kandang Terhadap Bobot Biji per Rumpun, Bobot Biji per Hektar, Indeks Panen, dan Rendemen Biji Pecah Kulit.

\begin{tabular}{|c|c|c|c|c|}
\hline Perlakuan & $\begin{array}{l}\text { Bobot Biji per } \\
\text { Rumpun (g) }\end{array}$ & $\begin{array}{l}\text { Bobot Biji } \\
\text { per Hektar } \\
\text { (ton) }\end{array}$ & $\begin{array}{c}\text { Indeks } \\
\text { Panen }\end{array}$ & $\begin{array}{c}\text { Rendemen } \\
\text { Biji Pecah } \\
\text { Kulit }\end{array}$ \\
\hline $\mathrm{A}=\mathrm{JK} 50 \times 50 \mathrm{~cm}+\mathrm{PK}$ ayam 5 ton $/ \mathrm{ha}$ & $194.78 \mathrm{~d}$ & $6.23 \mathrm{a}$ & $0.26 \mathrm{a}$ & $53.06 \mathrm{a}$ \\
\hline $\mathrm{B}=\mathrm{JK} 50 \times 50 \mathrm{~cm}+\mathrm{PK}$ kambing 5 ton $/ \mathrm{ha}$ & $194.44 \mathrm{~d}$ & $6.22 \mathrm{a}$ & $0.26 \mathrm{a}$ & $54.99 \mathrm{a}$ \\
\hline $\mathrm{C}=\mathrm{JK} 50 \times 50 \mathrm{~cm}+\mathrm{PK}$ sapi 5 ton $/$ ha & $193.00 \mathrm{~d}$ & $6.18 \mathrm{a}$ & $0.22 \mathrm{a}$ & $52.43 \mathrm{a}$ \\
\hline $\mathrm{D}=\mathrm{JK} 50 \times 75 \mathrm{~cm}+\mathrm{PK}$ ayam 5 ton $/ \mathrm{ha}$ & $210.67 \mathrm{bc}$ & $4.50 \mathrm{~b}$ & $0.28 \mathrm{a}$ & $51.02 \mathrm{a}$ \\
\hline $\mathrm{E}=\mathrm{JK} 50 \times 75 \mathrm{~cm}+\mathrm{PK}$ kambing 5 ton $/$ ha & $200.89 \mathrm{~cd}$ & $4.29 \mathrm{~b}$ & $0.25 \mathrm{a}$ & $51.16 \mathrm{a}$ \\
\hline $\mathrm{F}=\mathrm{JK} 50 \times 75 \mathrm{~cm}+\mathrm{PK}$ sapi 5 ton $/ \mathrm{ha}$ & $210.00 \mathrm{bc}$ & $4.48 \mathrm{~b}$ & $0.27 \mathrm{a}$ & $52.93 \mathrm{a}$ \\
\hline $\mathrm{G}=\mathrm{JK} 50 \times 100 \mathrm{~cm}+\mathrm{PK}$ ayam 5 ton $/$ ha & $223.55 \mathrm{a}$ & $3.58 \mathrm{c}$ & $0.29 \mathrm{a}$ & $53.20 \mathrm{a}$ \\
\hline $\mathrm{H}=\mathrm{JK} 50 \times 100 \mathrm{~cm}+\mathrm{PK}$ kambing 5 ton $/$ ha & $220.44 \mathrm{ab}$ & $3.53 c$ & $0.26 \mathrm{a}$ & $54.03 \mathrm{a}$ \\
\hline $\mathrm{I}=\mathrm{JK} 50 \times 100 \mathrm{~cm}+\mathrm{PK}$ sapi 5 ton $/ \mathrm{ha}$ & $213.00 \mathrm{abc}$ & $3.41 \mathrm{c}$ & $0.28 \mathrm{a}$ & $51.92 \mathrm{a}$ \\
\hline
\end{tabular}

Keterangan : JK = Jarak Tanam dan PK = Pupuk Kandang

Huruf yang sama setelah nilai rata-rata menunjukkan perbedaan yang nyata menurut uji Duncan pada taraf nyata $5 \%$

Bobot Biji per Rumpun dan Bobot Biji per

Hektar. Hasil analisis ragam mengenai bobot biji per rumpun dan bobot biji per hektar disajikan pada Tabel 4. Berdasarkan hasil analisis data statistik pada Tabel 4 diketahui bahwa pengaturan jarak tanam dan jenis pupuk kandang menunjukkan pengaruh berbeda nyata terhadap bobot biji per rumpun maupun per hektar. Pada perlakuan G tidak berbeda nyata dengan perlakuan $\mathrm{H}$ dan $\mathrm{I}$, namun berbeda nyata dengan perlakuan $\mathrm{A}, \mathrm{B}, \mathrm{C}, \mathrm{D}, \mathrm{E}$, dan $\mathrm{F}$ terhadap bobot biji per rumpun tanaman hanjeli yang lain. Hal ini diduga karena faktor populasi tanaman dalam satu petak yang membuat persaingan dalam mendapatkan unsur hara yang digunakan dalam pembentukan biji.

Sementara itu perlakuan A, B, dan C mempunyai bobot biji per hektar yang hampir sama tetapi lebih tinggi dibandingkan dengan perlakuan-perlakuan lainnya. Perlakuan A, B, dan $C$ lebih baik dari perlakuan lainnya akibat dominasi pengaruh jumlah populasi tanaman yang lebih banyak dibandingkan dengan populasi tanaman pada perlakuan lainnya. Efek dari peningkatan bobot biji akibat penambahan jarak tanaman tidak dapat mengimbangi efek peningkatan bobot biji akibat peningkatan populasi tanaman.

Tanaman yang memiliki pertumbuhan yang baik akan menghasilkan biji tanaman yang bernas. Hal ini berhubungan dengan sistem transportasi dan laju fotosintesis pada tanaman. Apabila terjadi kerusakan dalam sistem transportasi dan menurunkan laju fotosintesis, maka akan terjadi penumpukan fotosintat pada daun dan akan sulit ditranslokasikan ke seluruh organ tanaman dan menjadikan lambatnya pertumbuhan biji tanaman (Hidayat, 1992).
Indeks Panen. Nilai indeks panen merupakan perbandingan antara bobot kering organ hasil produksi dengan total bobot kering tanaman yang terbentuk (hasil pertumbuhan dan perkembangan tanaman mulai dari berkecambah sampai akhir pertumbuhan). Hasil analisis ragam mengenai indeks panen disajikan pada Tabel 4. Berdasarkan hasil analisis data statistik pada Tabel 4 diketahui bahwa pengaturan jarak tanam dan jenis pupuk kandang menunjukkan pengaruh tidak berbeda nyata pada setiap perlakuan terhadap indeks panen. Nilai indeks panen yang angkanya mendekati satu menunjukkan bahwa hampir semua organ tanaman yang terbentuk merupakan hasil tanaman yang bernilai ekonomis, jika semakin mendekati nilai nol berarti hanya sedikit organ yang bernilai ekonomis. Keberhasilan produksi tanaman mensyaratkan penggunaan sumber daya iklim, penyinaran matahari, karbon dioksida, dan air secara efisien. Pupuk sebagai sumber nutrisi relevan untuk pertumbuhan tanaman akan menunjang keberhasilan produksi akhir tanaman (Sudaryani dan Sugiharti, 1989).

Rendemen Biji Pecah Kulit. Nilai rendemen biji pecah kulit merupakan perbandingan antara bobot biji pecah kulit (tanpa kulit) dengan bobot biji berkulit. Hasil analisis ragam mengenai rendemen biji pecah kulit disajikan pada Tabel 4. Berdasarkan hasil analisis data statistik pada Tabel 4 diketahui bahwa pengaturan jarak tanam dan jenis pupuk kandang menunjukkan pengaruh tidak berbeda nyata pada setiap perlakuan terhadap rendemen biji pecah kulit. Hal ini diduga pembentukan biji dan kulit biji dipengaruhi oleh faktor genetik dan unsur $\mathrm{K}$ sebagai salah satu yang berperan 
dalam pembentukkan biji. Hal ini menunjukkan bobot biji tanpa kulit lebih besar dibandingkan bobot kulit biji. Hal ini diduga unsur yang berperan dalam pembentukan biji lebih besar daripada unsur yang berperan dalam pembentukan kulit biji.

\section{Kesimpulan}

Berdasarkan hasil penelitian maka dapat diperoleh simpulan sebagai berikut: (1) Pengaturan jarak tanam dan jenis pupuk kandang memberikan pengaruh pada indeks luas daun, bobot kering akar, dan bobot biji per rumpun, dan (2) Terdapat kombinasi jarak tanam dan jenis pupuk kandang yang memberikan hasil terbaik terhadap bobot biji per rumpun (Coix lacryma-jobi L.) pada perlakuan jarak tanam 50 × $100 \mathrm{~cm}$ dengan pupuk kandang ayam 5 ton per hektar.

\section{Daftar Pustaka}

Cahyono, B. 2002. Cara Meningkatkan Budidaya Kubis : Analisis Kelayakan, Secara Intensif, Jenis Kubis Putih. Yayasan Pustaka Nusantara. Yogyakarta.

Gardner dan Pearce. 1991. Fisiologi Tanaman Budidaya (terjemahan dari Physiology of Crop Plants oleh Herawati Susilo). Universitas Indonesia (UI Press), Jakarta.

Goldsworthy dan Fisher. 1992. Fisiologi Tanaman Budidaya Tropik (terjemahan dari The Physiology of Tropical Field Crops oleh Tohari). Gadjah Mada Univ. Press, Yogyakarta.

Harjadi, S.S. 1993. Pengantar Agronomi. Jakarta. Gramedia.

Hidayat, O.O. 1992. Morfologi Tanaman Kedelai. Balitbangtan Pusat Penelitian Tanaman Pangan. Bogor.

Kuyik, Antonius R., Pemmy Tumewu, D.M.F. Sumampow, dan E.G. Tulungen. 2012. Respons Tanaman Jagung Manis (Zea mays saccharata L.) terhadap Pemberian Pupuk Organik. Fakultas Pertanian Universitas Sam Ratulangi, Manado.

Marco, K. and K. Wunwisa. 2012, The Use of Job's Tear (Coix lacryma-jobi L.) Flour to Substitute Cake Flour in Butter Cake. Faculty of Biotechnology, Assumption University, Bangkok, Thailand.
Maruapey, Ajang. 2011. Pengaruh Jarak Tanam dan Jenis Pupuk Kandang Terhadap Pertumbuhan Gulma dan Hasil Jagung Manis. Libang Pertanian Kementrian Pertanian.

Moenandir, H. J., E. Widaryanto, dan Poejantoro. 1993. Periode Kritis Tanaman Kedelai karena Ada Persaingan dengan Gulma. Agrivita, 11(3): 24-29.

Nurmala, T. 1998. Serelia Sumber Karbohidrat Utama. Rineka Cipta. Jakarta.

Nurmala, T. dan A.W. Irwan. 2007. Pangan Alternatif Berbasis Serelia Minor. Penerbit Giratuna. Bandung.

Oldeman, L.R., 1975. Agroclimatic map of Java \& Madura. Contr. of Centra. Res. Inst. for Food Crops 16/76. Bogor.

Purwanto dan Rudi Hartono. 2005. Bertanam Jagung Unggul. Penebar Swadaya.Jakarta.

Rajagopal, V and Beringer. 1982. Potassium and Water Relations in Plant Potassium and Plant Physiology Procceduring. S of A. Group Discussion. Potash Research Institute, India.

Salisbury, F.B., dan C.W. Ross. 1995. Fisiologi tumbuhan. Jilid 1 Terjemahan Diah R. Lukman dan Sumaryo. ITB, Bandung.

Siarudin, M dan E. Suhaendah. 2007. Uji Pengaruh Mikoriza dan Cuka Kayu terhadap Pertumbuhan Lima Provenan Sengon di Pesemaian. Balai Besar Penelitian Bioteknologi dan Pemuliaan Tanaman Hutan Kehutanan Ciamis.

Silaban, S. 1994. Pengaruh Takaran Kompos dan Jarak Tanam Terhadap Karakteristik Agronomis Tanaman Nilam (Dogostemon cablin Benth). Padang. Faperta Unand.

Sitompul, S.M dan B. Guritno. 1995. Analisis Pertumbuhan Tanaman. Universitas Gadjah Mada. Yogyakarta.

Sudaryani, T dan E. Sugiharti. 1989. Budidaya dan Penyulingan Tanaman Nilam. Penebar Swadaya, Jakarta.

Suriadikarta dan Simanungkalit. 2006. Pupuk Organik dan Pupuk Hayati. Balai Besar Penelitian dan Pengembangan Sumberdaya Lahan Pertanian. Bogor.

Sutedjo, M. M. 2008. Pupuk dan Cara Pemupukan. Rineka Cipta, Jakarta.

Yelis, R. 2011. Peningkatan Produktivitas Hanjeli Indigenous Kiara Payung Sebagai Pangan Bergizi dengan Pemberian Pupuk N, P, K pada Dosis dan Waktu yang Berbeda. Budidaya Pertanian. Fakultas Pertanian Universitas Padjadjaran. 